\title{
Excretion of dissolved organic carbon by phytoplankton of different sizes and subsequent bacterial uptake
}

\author{
Nechama Z. Malinsky-Rushansky ${ }^{1,2, *}$, Catherine Legrand ${ }^{3}$ \\ ${ }^{1}$ Israel Oceanographic \& Limnological Research, Yigal Allon, Kinneret Limnological Laboratory, PO Box 345, Tiberias, Israel 14102 \\ ${ }^{2}$ Department of Life Sciences, Bar-Ilan University, Ramat Gan, Israel \\ ${ }^{3}$ Centre de Recherche en Ecologie Marine et Aquaculture de L'Houmeau, BP 5, F-17137 L'Houmeau, France
}

\begin{abstract}
Identical techniques and laboratory equipment were used to compare photosynthetic particulate assimilation and excretion of dissolved organic compounds (EOC) by different size classes of phytoplankton from marine and freshwater ecosystems. The subsequent assimilation and respiration of these algal exudates by bacteria were measured. The percentage of extracellular release of dissolved organic compounds was lower $(4$ to $5 \%$ ) for larger algal cells than for picoeukaryotes (29\%). Bacterial assimilation of the EOC released by the algae under these conditions seemed to be related more to algal species than to biovolume, although there may also be an effect on the specific bacterial assemblages. Bacterial uptake and utilization of EOC was $19 \%$ for freshwater picoeukaryotes, and 18 to $70 \%$ for marine nanoplankton. Great variations were found in the respiration rates of natural bacteria on EOC released by the freshwater picoalgae $(95 \%)$ and nanoplanktonic salt pond algae (20 to $41 \%)$.
\end{abstract}

KEY WORDS: Phytoplankton photosynthesis Excretion Subsequent bacterial uptake

\section{INTRODUCTION}

The dissolved organic carbon (DOC) pool in aquatic systems is composed of different sources such as runoff from the land, sloppy feeding and excretion from zooplankton (Jumars et al. 1989), lysis of plankton cells (Cole 1985), and excretion by phytoplankton (Brock \& Clyne 1984). Algal excretion of DOC (EOC) is defined as the DOC release during photosynthesis by a healthy population.

Phytoplankton excretion of DOC is considered in some studies as a continuous process (Larsson \& Hagström 1982), but others suggest that significant excretion is a response to extreme environmental stress, such as changes in the quantity and quality of the light (Berman \& Holm-Hansen 1974, Verity 1981 , Zlotnik \& Dubinsky 1989), or limitation of nutrient concentration (Lancelot 1983) or different physiological states (Ignatiades \& Fogg 1973). Problems in the com-

·E-mail:kinneret@datasrv.co.il monly used ${ }^{14} \mathrm{C}$-technique (Herbland 1974) and the use of different laboratory equipment and procedures make it hard to compare the photosynthetic and excretion rates by phytoplankton reported in different studies. Most of the data on excretion comes from in situ experiments (Berman \& Holm-Hansen 1974, Watanabe 1980). A wide variability of percentage of algal extracellular release (PER) has been reported in works in situ ( 0 to $80 \%)$, but the average in fast growing algae was $13 \%$ of total primary production (Baines \& Pace 1991). Some studies which gave high PER values were criticized as experimental artifacts (Lancelot 1983). The effect of irradiance intensity cannot be isolated in in situ experiments from other environmental factors such as temperature, salinity, oxygen concentration and light quality. Some data were obtained with laboratory cultures (Verity 1981). Zlotnik \& Dubinsky (1989) and Feuillade et al. (1990) reported a tight coupling between the rates of light dependent carbon fixation and of EOC.

Another reason for the great variability of EOC values is the difficulty in evaluating bacterial assimilation 
and respiration of these algal exudates (Riemann \& Sondergaard 1986). EOC may be important as a source of primary growth substrates for free-living bacteria (Larsson \& Hagström 1982). The importance of microbial food chains parallel to the conventional grazing ones in aquatic food webs is now recognised (Azam et al. 1983). The significance of phytoplankton excretion as contributor to the 'microbial loop' has been studied (Cole et al. 1982, Brock \& Clyne 1984). EOC contributed to about half of the bacterial carbon requirement in some environments (Larsson \& Hagström 1982). Some studies suggested that a considerable amount of the annual primary production passed through the bacterial component (Brock \& Clyne 1984), and bacterial production averaged $20 \%$ of planktonic primary production (Cole et al. 1988).

The goal of this study was to compare (1) the algal photosynthesis and excretion rates and (2) the proportion of photosynthetic excreted organic carbon (EOC) that passes through the bacterial component, in nanoand picoplanktonic eukaryotic algae from salt ponds and lake water, respectively, using identical techniques and laboratory equipment.

\section{MATERIAL AND METHODS}

Algal and bacterial cultures. Three algal cultures were examined. Navicula filata (bacillariophyte, 8 to $10 \mu \mathrm{m}$ ) and Pavlova lutheri (prymnesiophyte, 4 to $7 \mu \mathrm{m}$ ) were isolated from salt ponds on the Atlantic coast of France. The Chlorella-like picoeukaryote (1.5 to $2 \mu \mathrm{m}$ ) was isolated from Lake Kinneret, Israel (Malinsky-Rushansky \& Berman 1991). Marine cultures were grown axenically in salt pond water which was prefiltered on $0.2 \mu \mathrm{m}$ Nuclepore filters and autoclaved after enrichment with di-ammonium-phosphate (DAP) $\left(15 \mu \mathrm{M}\left(\mathrm{NH}_{4}\right)_{2} \mathrm{PO}_{4}\right)$. Two liter cultures were incubated in optimal growth conditions $\left(340 \mu \mathrm{E} \mathrm{m} \mathrm{m}^{-2} \mathrm{~s}^{-1}\right.$, photoperiod $15 \mathrm{~L}: 9 \mathrm{D}, 20^{\circ} \mathrm{C}$ ). Algae from late exponential phase cultures were used for the experiments (Legrand 1993). Non-axenic freshwater monoclonal picoeukaryotes were grown till exponential phase, in artificial medium BG-11 (Stanier et al. 1971) under continuous irradiance of $45 \mu \mathrm{E} \mathrm{m}^{-2} \mathrm{~s}^{-1}$ and temperature of $20^{\circ} \mathrm{C}$

The marine natural bacterial population was obtained after filtering salt pond water through $1 \mu \mathrm{m}$ Nuclepore filters. DAP was added for $3 \mathrm{~d}$ in the dark to the filtrate containing the bacteria. Although microscopic observations did not show variations in shape or size of the cultivated bacteria compared to the natural populations, we cannot exclude a selection of some bacterial species. These bacteria were added to the marine nanoplanktonic cultures in order to measure photosynthetic particulate assimilation (PA) and EOC in non-axenic algal cultures. Bacteria from freshwater non-axenic cultures of picoeukaryotes were obtained after filtering dark incubated samples on $0.4 \mu \mathrm{m}$ Nuclepore filters that were prerinsed with $50 \mathrm{ml}$ filtered (milliQ) water in order to prevent addition of DOC from the filters (Bloem et al. 1989). No chlorophyll was found in the filtrates containing the bacteria.

Photosynthetic particulate carbon assimilation (PA) and excretion (EOC). BOD bottles with $100 \mathrm{ml}$ of the algal cultures were incubated with ${ }^{14} \mathrm{C}$-bicarbonate (Steeman-Nielsen 1952) ( $\mathrm{NaH}^{14} \mathrm{CO}_{3}, \mathrm{CEA}_{1} 0.3 \mu \mathrm{Ci} \mathrm{ml}{ }^{-1}$ ) for $3 \mathrm{~h}$ under optimal irradiance and temperature conditions. At the end of the incubations, the bottles were immediately filtered in the dark. Duplicate subsamples of $15 \mathrm{ml}$ were filtered under low vacuum (max. $50 \mathrm{~mm}$ $\mathrm{Hg}$ ), to avoid cell breakage (Herbland 1974). Differential filtration was used to measure PA (.3 and $0.8 \mu \mathrm{m}$ Nuclepore filters for nano- and picoplankton, respectively), EOC rates ( $<0.2 \mu \mathrm{m}$ filtrates), and the subsequent bacterial assimilation of EOC (BA) $(0.2 \mu \mathrm{m}$ Nuclepore filters) (Fig. 1). All experiments included dark controls. Unincorporated inorganic radioactive carbon was removed by acidification of the filters in plastic scintillation vials with $0.5 \mathrm{ml} 2 \mathrm{~N} \mathrm{HCl}$, under a fume hood.

In order to measure the amounts of radioactive dissolved organic compounds that were released from the algae during incubation (EOC), the <0.2 $\mu \mathrm{m}$ filtrates were acidified with $100 \mu \mathrm{l} 0.1 \mathrm{~N} \mathrm{HCl}$, bubbled with air for $1 \mathrm{~h}$, and $2 \mathrm{ml}$ aliquots were measured. Controls were run by adding equivalent amounts of ${ }^{14} \mathrm{C}$-bicarbonate

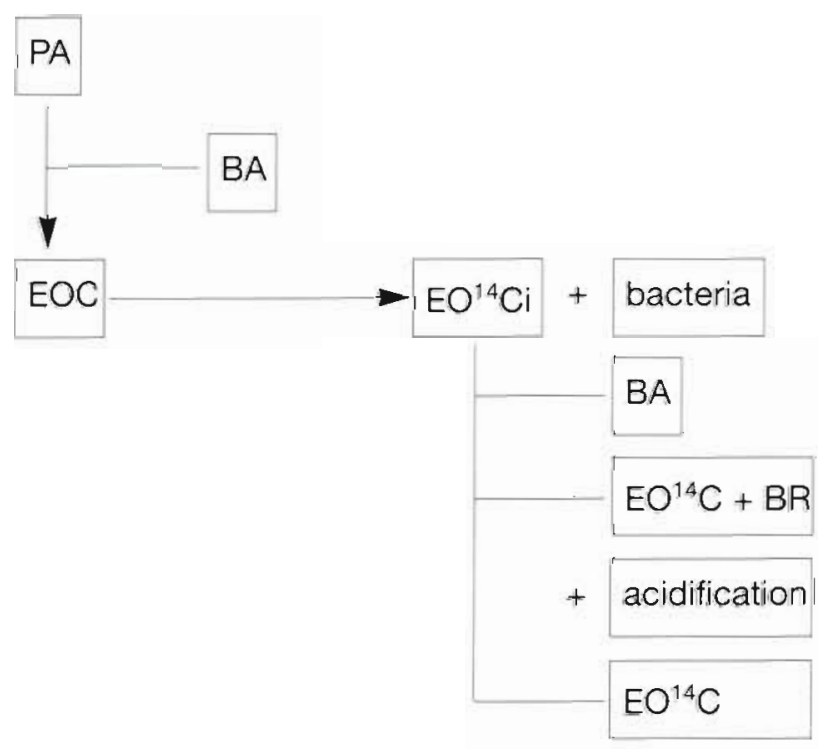

Fig. 1. Methodology of the experiment. PA: Photosynthetic particulate carbon assimilation, EOC: excretion of organic photosynthetate compounds, $\mathrm{EO}^{14} \mathrm{Ci}$ : initial EOC for measurement of $\mathrm{BA}, \mathrm{EO}^{14} \mathrm{C}$ : residual EOC, $\mathrm{BA}$ : bacterial assimilation of EOC. BR: bacterial respiration 
to 60 mi samples, and filtering immediately (blanks), as described above. All the samples were analysed for radioactivity after addition of $10 \mathrm{ml}$ Instagel in a Packard Tri Carb 1500 scintillation counter.

Extracellular release was expressed as PER of total assimilated ${ }^{14} \mathrm{C}$ :

$$
\mathrm{PER}=\mathrm{EOC} \times 100 /(\mathrm{PA}+\mathrm{EOC})
$$

where EOC is excreted dissolved organic ${ }^{14} \mathrm{C}$, and PA is particulate assimilated ${ }^{14} \mathrm{C}$ in the same volume, including EOC assimilated by bacteria

Bacterial uptake of EOC (BA) and respiration (BR). In order to measure the bacterial uptake and utilization of radioactive EOC, a $10 \mathrm{ml}$ aliquot from the bacterial sample was added to $60 \mathrm{ml}$ of $<0.2 \mu \mathrm{m}$ filtrate containing the radioactive $\mathrm{EO}^{14} \mathrm{C}$ (Fig. 1). The $\mathrm{pH}$ of the above acidified filtrates was first adjusted with sterile $\mathrm{NaOH}$ to in situ values. Final concentrations of bacteria were similar to those observed in natural samples. After $3 \mathrm{~h}$ incubation in the dark, 4 subsamples of $15 \mathrm{ml}$ were filtered on $0.2 \mu \mathrm{m}$ Nuclepore filters. The radioactivity retained on the filters corresponded to the radioactive EOC assimilated by bacteria (BA).

In order to obtain residual excreted radioactively labelled $\mathrm{EO}^{14} \mathrm{C}, 2$ of the above filtrates were acidified and bubbled with air for $1 \mathrm{~h}$. Both remaining filtrates were bubbled without acidification to obtain the residual $\mathrm{EO}^{14} \mathrm{C}$ along with the inorganic ${ }^{14} \mathrm{CO}_{2}$ resulting from bacterial respiration (BR). BR was obtained after subtracting the residual $E \mathrm{O}^{14} \mathrm{C}$ from the fractions containing $\mathrm{EO}^{14} \mathrm{C}+\mathrm{BR}$.

Chlorophyll $a$, algal and bacterial cell counts. Samples $(2$ to $10 \mathrm{ml}$ ) were filtered on glass fiber filters (GF/F Whatman). Chlorophyll a (chl a) was extracted in methanol and measured with a Turner model 112 fluorimeter (Holm-Hansen \& Riemann 1978). The chl a values used in our calculations are those from the beginning of the experiment (Table 1). In order to assess the separation between 'algal' and 'bacterial' samples after filtration, we checked the chl a content in both fractions.
Subsamples were fixed with formaldehyde $(2 \%$ final concentration) and counted with an epifluorescent microscope (Zeiss Axioscope). Algal cells were counted using their autofluorescence, while bacteria were stained with acridine orange (Hobbie et al. 1977).

\section{RESULTS AND DISCUSSION}

\section{Photosynthetic particulate ${ }^{14} \mathrm{C}$-carbon assimilation (PA)}

Dark values were not subtracted from those measured in the light, because different mechanisms of carbon fixation were probably functioning in the 2 cases (Watanabe 1980). Two experiments were carried out, showing the same general trend of results, but in this paper we present in detail the result of the more comprehensive of the 2 experiments. Because experimental samples were always run in duplicate, we show the results in Tables $1 \& 2$ as ranges. Averages were taken for calculations of the photosynthetic parameters. In the dark, picoeukaryotes assimilated $40 \%$ of the carbon fixation in the light, while dark carbon fixation was less significant in the nanoplanktonic cultures (average of $0.4 \%$ for Pavlova lutheri and $1.9 \%$ for Navicula filata) (Table 1).

Photosynthetic rates in picoeukaryotes were similar to those found in Lake Kinneret at the period of picoeukaryote abundance (June), as well as in picoeukaryotic cultures from lake isolates ( $\mathrm{N}$ Z. MalinskyRushansky unpubl. data). Cell specific rates of carbon assimilation were obtained by dividing PA values by initial algal cell numbers, assuming that no significant differences occurred during the incubation in the numbers, physiological state and size of the cells. The values of cellular PA for nanoplankton were 2 to 7 times higher than for picoeukaryotes, although no relation to the nanoplanktonic cell size was observed. Assimilation numbers showed no relation to algal size and were similar for Navicula filata and picoeukaryotes, but were almost 2 times higher for Pavlova lutheri.

Table 1. Algal abundance $\left(10^{4}\right.$ cells $\left.\mathrm{ml}^{-1}\right)$ and chlorophyll a $\left(\mu \mathrm{gl}^{-1}\right)$ at the beginning of the incubation. Photosynthetic particulate carbon assimilation (PA) ( $\left.\mu \mathrm{g} \mathrm{C} \mathrm{l}^{-1} \mathrm{~h}^{-1}\right)$, PA per cell (PA/cell, $\mu \mathrm{g} \mathrm{C}$ cell $\left.{ }^{-1} \mathrm{~h}^{-1}\right)$, and assimilation numbers $\left.(\mathrm{AN})(\mu \mathrm{g} \mathrm{C} \mu \mathrm{g} \mathrm{ch}]^{-1} \mathrm{~h}^{-1}\right)$ of axenic $(A X)$ and non-axenic $(+B)$ algal cultures. Values from duplicate samples are presented as ranges. Averages were taken for calculations of PA/cell and AN

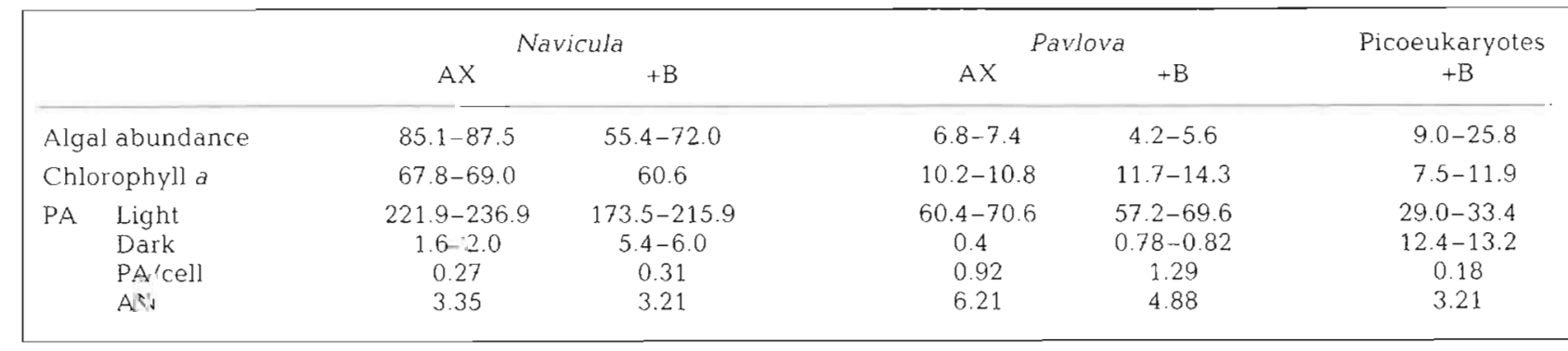


Table 2. Excretion of organic compounds (EOC) ( $\mu \mathrm{g} C \mathrm{l}^{-1} \mathrm{~h}^{-1}$ ) by 3 algal axenic $(A X)$ and non-axenic $(+B)$ cultures, subsequent bacterial assimilation (BA) ( $\left.\mu \mathrm{C} \mathrm{C}^{-1} \mathrm{~h}^{-1}\right)$, and percentage of extracellular release (PER) (\%). Values from duplicate scimples are presented as ranges. Averages were taken for calculations of EOC+BA and PER

\begin{tabular}{|c|c|c|c|c|c|}
\hline & \multicolumn{2}{|c|}{ Navicula } & \multicolumn{2}{|c|}{ Pavlova } & \multirow{2}{*}{$\begin{array}{c}\text { Picoeukaryotes } \\
+\mathrm{B}\end{array}$} \\
\hline & $A X$ & $+B$ & $A X$ & $+B$ & \\
\hline $\mathrm{EOC}$ & $7.77-7.83$ & $6.6-7.8$ & $2.4-2.8$ & $1.2-1.6$ & $3.98-4.02$ \\
\hline $\mathrm{BA}$ & 0 & 0 & 0 & $0.9-1.5$ & 0.4 \\
\hline $\mathrm{EOC}+\mathrm{BA}$ & 7.8 & 7.2 & 2.6 & 2.6 & 4.4 \\
\hline PER & 3.3 & 3.6 & 3.8 & 3.8 & 12.4 \\
\hline
\end{tabular}

Table 3. Excretion of organic compounds by different phytoplanktonic cultures. Modified from Legrand (1993)

\begin{tabular}{|lccll}
\hline Algal species & Size $(\mu \mathrm{m})$ & PER (\%) & \multicolumn{1}{c|}{ Source } \\
\hline Synechococcus sp. & 1 & $10-15$ & Zlotnik \& Dubinsky (1989) \\
Chlorella-like & $1.5-2$ & 12.4 & This study \\
Isochrysis galbana & $4-6$ & 10 & Zlotnik \& Dubinsky (1989) \\
Chlorella vulgaris & $1.5-10$ & 4 & Zlotnik \& Dubinsky (1989) \\
Pavlova lutheri & $3-10$ & $3.6-4.5$ & Ignatiades \& Fogg (1973) \\
& $4-7$ & $3-4$ & This study \\
Navicula filata & $6-10$ & $3-5$ & This study \\
Leptocylindrus danicus & $5-16$ & $1.3-9$ & Verity (1981) \\
Skeletonema costatum & $3-20$ & $4.6-9$ & Ignatiades \& Fogg (1973) \\
Oscillatoria & $3-30$ & $<3$ & \\
& & 1 & Nalewajko (1966) \\
Chlamydomonas provasolii & $5-30$ & 5.6 & Saks (1982) \\
Chaetoceros affinis & $9-30$ & 9 & Myklestad et al. (1989) \\
Thalassiosira fluviatilis & $18-50$ & 5 & Sharp (1977) \\
\hline
\end{tabular}

Our results (Table 1 ) suggest that the photosynthetic parameters measured (PA and EOC) are not related to algal size and physiological state, but to the species

In order to measure if all the chlorophyll was retained in the algal fraction, the bacterial fractions were filtered on GF/F filters. All picoeukaryotic chlorophyll was retained on $0.8 \mu \mathrm{m}$ filters, and the loss for nanoplanktonic chlorophyll was less than $7 \%$. This suggests that assimilation numbers found for picoeukaryotes are correctly evaluated, while those found for nanoplankton could be slightly overestimated.

\section{Algal excretion of dissolved ${ }^{14} \mathrm{C}$-organic compounds (EOC)}

The excretion of photosynthetic carbon was perceptible in all 3 algal cultures. The PER relative to total carbon fixed was calculated, including BA, from the non-axenic cultures (Table 2) PER values were about 3 -fold higher for freshwater picoeukaryotes (12\%) than for marine nanoplanktonic algae ( 3 to $4 \%$ ). The 2 marine nanoplanktonic cultures had similar PER values (Table 2).

The PER values ( 3 to $12 \%$ ) in our experiments agreed with those found in other studies (Table 3). Smaller algae $(<5 \mu \mathrm{m}$ ) showed higher ( $>10 \%$ ) PER values (Table 3), perhaps due to their generally higher metabolic rate (Reynolds 1984).

In in situ studies, PER varied from 0 to $70 \%$ (Sundh 1989, Gomes et al. 1991). Higher PER values were found at low and very high irradiances, when photosynthesis was reduced, near the surface or at the bottom of the euphotic zone (Berman \& Holm-Hansen 1974, Watanabe 1980 , Larsson \& Hagström 1982). In our experiments, we used optimal light intensities and temperature for growth, probably resulting in lower PER valucs compared to those observed in nature with different environmental factors

\section{Bacterial uptake of algal excreted organic compounds (EOC)}

We tried to estimate the bacterial uptake and utilization of algal $\mathrm{EO}^{14} \mathrm{C}$ and to differentiate between the 'assimilation' (BA) and the 'respiration' (BR) (Fig. 1). Bacterial numbers in the filtrate containing algal $\mathrm{EO}^{14} \mathrm{C}$ corresponded approximately to those found in the original algal cultures during the light experiments. Here we give values as percentages to minimize the effect of changes in specific activity of ${ }^{14} \mathrm{CO}_{2}$ and $\mathrm{EO}^{14} \mathrm{C}$ in our experiments (Table 4).

In the light experiments (Fig. 1), PER was calculated relative to total carbon fixed, including $\mathrm{BA}$ in the nonaxenic algal cultures, and residual EOC, as in the

Table 4. Bacterial assimilation (BA) and respiration (BR) of EOC. All values are in \%

\begin{tabular}{|c|c|c|c|}
\hline & Navicula & Pavlova & Picoeukaryotes \\
\hline \multicolumn{4}{|l|}{ EOC uptake (total) } \\
\hline $\mathrm{EO}^{14} \mathrm{Ci}-\mathrm{EO}^{14} \mathrm{C}^{\mathrm{a}}$ & 72.0 & 18.2 & 19.3 \\
\hline $\mathrm{BA}+\mathrm{BR}^{\mathrm{b}}$ & 69.8 & 18.2 & 18.6 \\
\hline EOC respiration ${ }^{\mathrm{C}}$ & 19.6 & 40.6 & 95.1 \\
\hline \multicolumn{4}{|c|}{$\begin{array}{l}\text { a Assimilated EOC, calculated as the difference between } \\
\text { Initial and residual EOC }\end{array}$} \\
\hline \multicolumn{4}{|c|}{$\begin{array}{l}\text { bAssimilated EOC, calculated as the sum of bacterial } \\
\text { assimilation and respiration }\end{array}$} \\
\hline \multicolumn{4}{|c|}{$\begin{array}{l}\text { "Respired EOC from total assimilated EOC, calculated as } \\
\mathrm{BR} \times 100 /\left(\mathrm{EO}^{14} \mathrm{C}-\mathrm{E} \mathrm{O}^{14} \mathrm{C}\right)\end{array}$} \\
\hline
\end{tabular}


method of Riemann \& Søndergaard (1986). The differences in values of residual EOC found in axenic and non-axenic cultures of Pavlova lutheri were probably due to bacterial assimilation of EOC, which was mostly recovered in the bacterial fraction $B A$ (Table 2). In terms of carbon, BA was $1.4 \%$ of particulate assimilated carbon for picoeukaryotes and $1.9 \%$ for $P$. lutheri, and accounted for $10 \%$ and $46 \%$ of the EOC excreted by picoeukaryotes and $P$. lutheri. respectively, assuming that the specific activity was the same in all compartments. BA of EOC was not observed in the nonaxenic cultures of Navicula filata in the light, probably because of a filtration error. It is unlikely, however, that there was no $\mathrm{BA}$, because significant $\mathrm{BA}$ of labelled $E O^{14} \mathrm{C}$ was found during the dark incubation.

In the dark experiments, we attempted to quantify bacterial utilization of total algal EOC, including $\mathrm{BA}$ and $\mathrm{BR}$, by adding radioactive $\mathrm{EO}^{14} \mathrm{C}$ (obtained as $<0.2 \mu \mathrm{m}$ filtrate from the algal cultures) to natural marine or freshwater bacterial populations. We assumed that no algae passed the $0.2 \mu \mathrm{m}$ filters and in consequence, all radioactivity subsequently found in particles was considered to result from bacterial uptake of algal $E O^{14} \mathrm{C}$.

The percentage of bacterial utilization of excreted organic compounds $E \mathrm{O}^{14} \mathrm{C}$, calculated as the difference between the initial and the residual $\mathrm{EO}^{14} \mathrm{C}$, was about 3.5-fold higher for EOC from Navicula filata $(72 \%)$ than from Pavlova lutheri $(18 \%)$ and picoeukaryotes (19\%) (Table 4 ) and could result from differences in the efficacy of bacteria in assimilating EOC from different sources and of different composition (Bell 1984). Bacterial uptake depends on the kinds of algal EOC released and probably also on the bacterial species and their origin. Bacterial assemblages were almost certainly different in freshwater and in salt ponds. We used the same bacterial population with the $\mathrm{EO}^{14} \mathrm{C}$ from the 2 marine nanoplanktonic cultures, and the difference in response suggests a different composition of $E \mathrm{O}^{14} \mathrm{C}$. For the non-axenic picoeukaryote

Table 5. Uncorrected (UN) and corrected (COR) values of total photosynthetic particulate carbon assimilation (PA) and excretion (EOC) in non-axenic algal cultures. Values of PA and EOC are in $\mu \mathrm{g} \mathrm{Cl}^{-1} \mathrm{~h}^{-1}$, and of PER in \%

\begin{tabular}{|c|c|c|c|c|c|c|}
\hline & \multicolumn{2}{|c|}{ Navicula } & \multicolumn{2}{|c|}{ Pavlova } & \multicolumn{2}{|c|}{ Picoeukaryotes } \\
\hline & UN & COR & UN & COR & UN & COR \\
\hline $\mathrm{EOC}^{\mathrm{a}}$ & 7.2 & 7.2 & 1.4 & 3.4 & 4.0 & 12.8 \\
\hline $\mathrm{PA}^{b}$ & 194.7 & 202.0 & 63.4 & 66.8 & 31.2 & 44.0 \\
\hline PER & 3.6 & 3.6 & 3.8 & 5.0 & 12.4 & 29.1 \\
\hline \multicolumn{7}{|c|}{$\begin{array}{l}\text { Total EOC, corrected for bacterial assimilation and } \\
\text { respiration (EOC + BA + BR) }\end{array}$} \\
\hline
\end{tabular}

culture, bacteria more adapted to using the specific composition of EOC released may have been selected. The composition of EOC could also be affected by volatile and acid unstable compounds that may escape after acidification and bubbling, and this may explain the slightly higher values $10.7 \%$ for picoeukaryotes and $2.2 \%$ for $N$. filatal found for bacterial utilization (EOC uptake), when calculated from the difference between initial and residual $E \mathrm{O}^{14} \mathrm{C}$, compared to those calculated from the sum of bacterial assimilation and respiration (Table 4 ).

Large variations were found in the respiration rates of EOC by natural bacterial population from the salt pond (20 to $41 \%$ ) and from freshwater ( $95 \%$ ). Respiration rates were calculated as the percentage of $B R$ of the total EOC uptake (Table 4). Respiration rates obtained for bacterial salt pond population were similar to those found for bacteria in complex nutritive medium (Payne \& Wiebe 1978). The high percentage for BR (95\%) of picoeukaryotic EOC can explain the low percentage $(0.3 \%)$ found for BA of EOC. High BR rates on EOC ( 80 to $95 \%$ ) were also reported by Billen et al. (1980) and Itturiaga \& Zsolnay (1981).

Most of the picoeukaryotic EOC (95\%) was respired by bacteria, while only a small part $(5 \%)$ of the EOC used was assimilated and used to increase the biomass. However, no increase in bacterial cell numbers was observed. More than half of the EOC released by Pavlova lutheri and Navicula filata 159 and $80 \%$, respectively), was utilized to increase the bacterial biomass, but increase in bacterial cell numbers was noted only with EOC released from $N$. filata (from $86.3 \times$ $10^{4} \pm 1.2 \times 10^{4}$ to $96.7 \times 10^{4} \pm 1.2 \times 10^{4}$ cells $\mathrm{ml}^{-1}$ ). This finding could be related to the high percentage of EOC uptake $(72 \%)$ which was then relatively efficiently utilized $(80 \%)$ to increase cell numbers. We have no information on slight changes in bacterial cell sizes that could result from the increase in biomass without increase in cell numbers.

\section{Algal photosynthetic assimilation (PA) and excretion (EOC) corrected for total bacterial uptake}

Values of gross photosynthetic carbon fixation may be underestimated if EOC and bacterial uptake are not taken into account. Total bacterial uptake was reevaluated as the sum of EOC assimilated but not respired, which was found in the bacterial fraction during the light experiment with phytoplankton (Table 1), plus the amount of EOC respired (derived from Table 4), assuming that specific activity was the same during the incubation period. With this correction, total PA was $5 \%$ higher for Pavlova Iutheri and 29\% higher for picoeukaryotes (Table 5). Photosynthetic parameters 
for Navicula filata may be slightly $(<4 \%)$ underestimated, because there was no correction due to bacterial uptake and utilization of EOC. The percentage of extracellular release (PER) was $22 \%$ and $57 \%$ higher for $P$. lutheri and picoeukaryotes, respectively. Our results show underestimates ( 10 to $26 \%$ ) similar to those noted by Baines \& Pace (1991) in measurements of primary production of natural communities when dissolved organic production is ignored.

\section{Fluxes of carbon through algal excretion}

Carbon fluxes (given as $\mu \mathrm{g} \mathrm{C}^{-1} \mathrm{~h}^{-1}$ ) from algal photosynthetic carbon assimilation to the bacterial biomass via algal excretion are summarized and compared in Fig. 2. Values were higher with freshwater piroukaryotes compared to the 2 marine algal cultures (12.8 and 3.4 to $7.2 \mu \mathrm{g} \mathrm{C}]^{-1} h^{-1}$, respectively). Although absolute carbon excretion was 2 -fold higher for Navicula filata, the PER was similar in the 2 marine algal cultures ( 4 to $5 \%$ ), and was $29 \%$ for picoeukaryotes. The efficiency of EOC uptake by bacteria was highest with EOC from $N$. filata $(70 \%)$ and similar with EOC from Pavlova lutheri and picoeukaryotes (18 and 19\%, respectively), suggesting no relation to algal size and

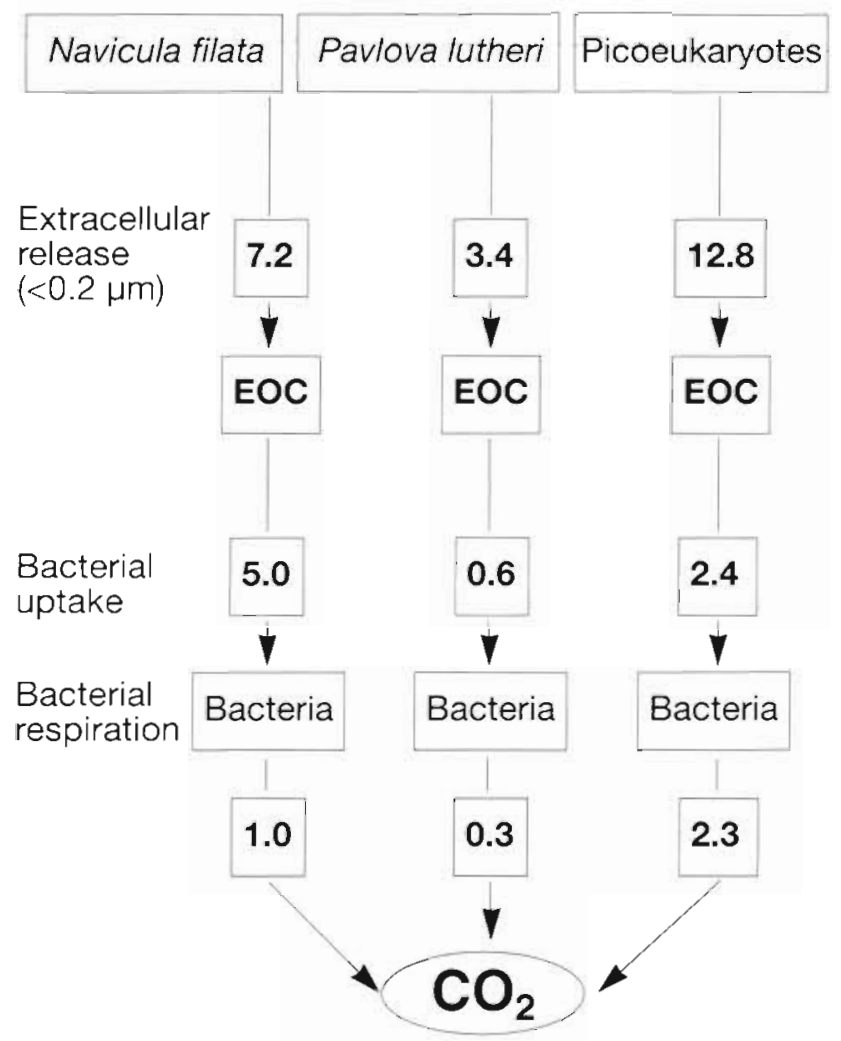

Fig. 2. Carbon fluxes (as $\mu \mathrm{g} \mathrm{Cl}^{-1} h^{-1}$ ) from algal photosynthetic carbon assimilation, through excretion to bacteria environment. BR of EOC (as $\mu \mathrm{g} \mathrm{C} \mathrm{I}^{-1} \mathrm{~h}^{-1}$ ) from freshwater picoeukaryotes was 2 and 7 times higher than for marine $N$. filata and $P$. lutheri, respectively. Assuming that the average biovolume of bacteria from salt ponds and Lake Kinneret in our experiments are 0.071 and $0.025 \mathrm{\mu m}^{3}$, respectively, with a carbon content of $0.22 \mathrm{pg} \mathrm{C} \mu \mathrm{m}^{-3}$ (Bratbak \& Dundas 1984), the residence time for EOC in bacteria was lower in those growing with $N$. filata and $P$. lutheri $(0.4$ to $4.6 \mathrm{~d})$ than in those growing with picoeukaryotes (22 d)

We conclude that bacterial uptake of algal EOC can be an important component of the carbon flux and should be determined as part of total photosynthetic carbon fixation. Because we used identical techniques, we could compare and conclude that excretion was higher in picoeukaryotes than in nanoplanktonic cultures. BA of EOC depended more on the algal species and the bacterial specific assemblage than on the algal biovolume. $\mathrm{BR}$ rates on EOC were much hugher in freshwater picoeukaryotes in cultures.

Acknowledgements. This work was supported by a 'Bourse Chateau-briand' from The Ministry of Foreign Affairs. France, IFREMER Poitou-Charentes grant and Grant 1932-1-93 from the Ministry of Science and the Arts, Jerusalem, Israel. The experiments were made in the Laboratoire CNRS-IFREMER, Crema-L'Houmeau, France. We thank $T$ Berman, A. HerbIand and D. Delmas for their uselul comments on the manuscript, as well as L. Joassard for technical help with the chlorophyll samples. This manuscript is a part of the $\mathrm{PhD}$ thesis of N.Z.M., Bar Ilan University, Israel.

\section{LITERATURE CITED}

Azam F, Fenchel T, Field JG, Gray JS, Meyer-Reil LA, Thingstad $F$ (1983) The ecological role of water-column microbes in the sea. Mar Ecol Prog Ser 10:257-263

Baines SB, Pace ML (1991) The production of dissolved organic matter by phytoplankton and its importance to bacteria: patterns across marine and freshwater systems. Limnol Oceanogr 36:1078-1090

Bell WH (1984) Bacterial adaptation to low nutrient conditions as studied with algal extracellular products. Microb Ecol 10:217-230

Berman T, Holm-Hansen $O$ (1974) Release of photoassimilated carbon as dissolved organic matter by marine phytoplankton. M.ar Biol 28:305-310

Billen G, Joiris C, Wynant J, Gillain G (1980) Concentration and microbiological utilization of small organic molecules in the Sheldt estuary, the Belgian coastal zone of the North Sea and the English Channel. Estuar coast mar Sci 11: $279-294$

Bloem J, Albert C, Bar-Gillissen MJB, Berman T, Cappenberg I (1989) Nutrient cycling through phytoplarıkton, bacteria and protozod in selectively filtered Lake Vechten water. J Plankton Res 11:119-131

Bratbak G, Dundas I (1984) Bacterial dry matter content and biomass estimations. Appl environ Microbiol 48:755-757

Brock TD. Clyne J (1984) Significance of algal excretory products for growth of epilimnetic bacteria. Appl environ Microbiol 47.731-734 
Cole JJ (1985) Decomposition. In: Likens GE (ed) An ecosystem approach to aquatic ecology: Mirror Lake and its environment. Springer-Verlag, New York, p 302-310

Cole JJ, Findlay S, Pace M. IL (1988) Bacterial production in fresh and saltwater ecosystems: a cross-system overview. Mar Ecol Prog Ser 43:1-10

Cole JJ, Likens GE, Strayer DL (1982) Photosynthetically produced dissolved organic carbon: an important source for planktonic bacteria. Limnol Oceanogr 27:1080-1090

Feuillade M, Feuillade J, Fiala V (1990) The effect of light on the release of organic compounds by the cyanobacterium Oscillatoria rubescens. Aquat Sci 52:345-359

Gomes Do RH. Pant A, Goes JI, Parulekar AH (1991) Heterotrophic utilization of extracellular products of phytoplankton in a tropical estuary. J Plankon Res 13:487-498

Herbland A (1974) Influence de la dépression de filtration sur la mesure simultanée de l'assimilation et de l'excrétion organique du phytoplancton. Cah ORSTOM Ser Oceanogr 12:173-178

Hobbie JE, Daley RJ, Jasper S (1977) Use of nuclepore filters for counting bacteria by fluorescence microscopy. Appl environ Microbiol 33:1225-1228

Holm-Hansen O, Riemann B (1978) Chlorophyll a determination improvments in methodology. Oikos 30:438-447

Ignatiades L, Fogg EG (1973) Studies on the factors affecting the release of organic matter by Skeletonema costatum (Greville) Cleve in culture. J mar biol Ass UK 53:937-956

Itturiaga R, Zsolnay A (1981) Differentiation between autoand heterotrophic activity problems in the use of size fractionation and antibiotics. Botanica Mar 24:399-404

Jumars PA, Penry DL, Barros JA, Perry MJ, Frost BW (1989) Closing the microbial loop: dissolved carbon pathway to heterotrophic bacterla from incomplete ingestion, digestion and absorption in animals. Deep Sea Res 36:483-495

Lancelot C (1983) Factors affecting phytoplankton extracellular release in the Southern Bight of the North Sea. Mar Ecol Prog Ser 12:115-121

Larsson U, Hagström A (1982) Fractionated phytoplankton primary production, exudate release and bacterial production in a Baltic eutrophication gradient. Mar Biol 67 $57-70$

Legrand C (1993) Production primaire et bactérienne en marais maritimes: excrétion organique algale et utilisation

This article was submitted to the editor par les bactéries. Thèse doctorat, U.P.S. Toulouse III

Malinsky-Rushansky NZ, Berman T (1991) Picocyanobacteria and bacteria in Lake Kinneret. Int Rev ges Hydrobiol 76 : $555-564$

Myklestad S, Holm-Hansen O, Varum KM. Volcani BE (1989) Rate of release of extracellular amino acids and carbohydrates from the marine diatom Chaetoceros affinis. J Plankton Res 11:763-773

Nalewajko C (1966) Photosynthesis and excretion in various planktonic algae. Limnol Oceanogr 11:1-10

Payne WJ, Wiebe WJ (1978) Growth yield and efficiency in chemosynthetic microorganusms. A Rev Microbiol 32: $155-183$

Reynolds CS (1984) The ecology of freshwater phytoplankton. Cambridge University Press, Cambridge

Riemann B, Sondergaard M (1986) Carbon dynamics in eutrophic temperate lakes. Elsevier Science Publishers BV, Amsterdam

Saks NM (1982) Primary production and release of assimilated carbon by Chlamydomonas provasolii in culture. Mar Biol 70:205-208

Sharp JH (1977) Excretion of organic matter by marine phytoplankton: do healthy cells do it? Limnol Oceanogr 22:381-399

Stanier RY, Kunisawa R, Mandel M, Cohen-Bazire G (1971) Purification and properties of unicellular blue-green algae (order Chroococcales). Bacteriol Rev 35:171-205

Steeman-Nielsen E (1952) The use of radioactive carbon $\left({ }^{14} \mathrm{C}\right.$ ) for measuring organic production in the sea. $\mathrm{J}$ Cons perm int Explor Mer 18:117-140

Sundh I (1989) Characterization of phytoplankton extracellular products (PDOC) and their subsequent uptake by heterotrophic organisms in a mesotrophic forest lake. J Plankton Res 11:463-486

Verity PG (1981) Effects of temperature, irradiance, and daylength on the marine diatom Leptocylindrus danicus Cleve. II. Excretion. J exp mar Biol Ecol 55:809-834

Watanabe Y (1980) A study of the excretion and extracellular products of natural phytoplankton in Lake Nakanuma, Japan. Int Rev ges Hydrobiol 65:809-834

Zlotnik I, Dubinsky Z (1989) The effect of light and temperature on DOC excretion by phytoplankton. Limnol Oceanogr $34: 831-839$

Manuscript first received: December 1,1994

Revised version accepted: August 24, 1995 